\title{
曲げーせん断組合せ荷重を受けるハイブリッド桁の せん断耐荷力性状に関する一考察
}

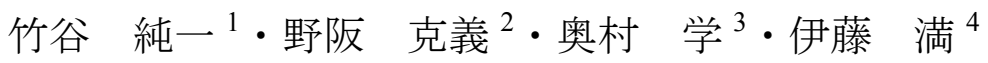 \\ 1 学生会員 立命館大学大学院生（干525-8577 滋賀県草津市野路東 1-1-1） (現・大成建設株式会社) \\ 2 正会員 立命館大学講師 理工学部（广525-8577 滋賀県草津市野路東 1-1-1） \\ E-mail: k-nozaka@se.ritsumei.ac.jp \\ 3 正会員 片山ストラテック(株) 技術本部 設計部（†551-0021 大阪府大阪市大正区南恩加島 6-2-21） \\ E-mail: okumura@katayama-st.co.jp \\ 4 正会員 立命館大学教授 理工学部（广525-8577 滋賀県草津市野路東 1-1-1） \\ E-mail: mitsuru@se.ritsumei.ac.jp
}

\begin{abstract}
近年の高強度鋼材の開発，および限界状態設計法へと移行する流れの中，鋼橋においては，フランジと ウェブに異なる強度の鋼材を用いたハイブリッド桁の適用が検討されてきている．八イブリッド栴の限界 状態設計法の確立には未だ基礎となるデータが少ないと考え，曲げ一せん断組み合わせ荷重を受けるハイ ブリッド桁の静的載荷試験を行い，おもにせん断耐荷力，曲げ一せん断の相関について検討した.

本研究で対象としたウェブ幅厚比においては, 曲げーせん断の相関は認められなかった. ハイブリッド 桁においてはウェブが先行降伏し, 耐荷力が低下寸ると考えられていたが, ウェブ内の応力状態を検討し た結果，そのような耐荷力の低下が起こらないことが確認された。また，実験結果との比較によりせん断 耐荷力提案式の精度を確認した。
\end{abstract}

Key Words : LRFD, tension field action, shear strength, hybrid plate girder

\section{1. まえがき}

近年の高強度構造用鋼材の開発に伴い，鋼橋を含む各 種鋼構造物における鋼材使用量を軽減し，構造物の軽量 化が可能となった ${ }^{1,2)}$. さらに，鋼橋においては，異種鋼 材を組み合わせて断面を形成するハイブリッド析の使用 が検討されてきている3）, 高強度鋼を用いる場合には， ホモジニアス桁（全断面に同一鋼材を用いた桁）よりも ハイブリッド析とした方が，経済性に優れた設計が可能 であるという研究結果も発表されている5゙7).

限界状態設計法の考え方を取り入れ，断面の降伏も含 んだ最大耐荷力をもとにした照査が規定されている米国 では，これまでにハイブリッド析に関する研究が行われ， ハイブリッド析の適用が可能であると示方書の中で明記 されている8-12)。一方，我が国においてもハイブリッド 桁の経済性に着目した研究も進められてきたが13-22)，許 容応力度設計法が基本となっている現行の道路橋示方書 では，曲げを受ける場合にウェブが先行降伏するという ハイブリッド栴の特徵のため実橋への適用が難しい. 我 が国でも性能照査型設計法へと移行しつつあり，今後八 イブリッド桁の適用が可能になるものと思われるが，そ
のための基礎的データは未だ少ないと考えられる.

せん断耐荷力における後座屈強度は, 我が国では安全 率を低くすることにより示方書に取り入れられている23). これに対して，米国のAASHTO（The American Association of State Highway and Transportation Officials) は, 2004年度版LRFD（Load and Resistance Factor Design）の 中で，ホモジニアス桁とハイブリッド栴のせん断耐荷力 に，後座屈強度を含んだ同一の式を規定し，さらに曲げ 一せん断の相関が無いものとした ${ }^{12)}$.

2004年度版LRFDにおいても用いられているように, せん断耐荷力式では, 斜張力場作用を含んだ形のBasler の式が広く知られている ${ }^{24), 25)}$ ，その後多くのせん断耐荷 力に関する式が提案，比較されてきているが ${ }^{20-33)}$,

Baslerの式が用いられているのはその式の簡便さにある ものと考えられる. しかしながら， Baslerの式が考案さ れた時にはハイブリッド桁に関する検討はなされてはお らず，安易にハイブリッド桁に適用することはできない と考えられる ${ }^{34}$. 特に, わが国で用いられている鋼材の 特性に応じた検討を行い, 簡便な設計式の提案が必要と 考えられる.

本研究は, 曲げ一せん断組合せ荷重によるハイブリッ 
表-1 供試体実測寸法

\begin{tabular}{|c|c|c|c|c|c|c|c|c|c|c|c|c|}
\hline 年度 & 供試体 & $\begin{array}{c}b \\
(\mathrm{~mm})\end{array}$ & $\begin{array}{c}t_{f} \\
(\mathrm{~mm})\end{array}$ & $\begin{array}{c}D_{w} \\
(\mathrm{~mm})\end{array}$ & $\begin{array}{c}t_{w} \\
(\mathrm{~mm})\end{array}$ & $\begin{array}{c}d_{0} \\
(\mathrm{~mm})\end{array}$ & $\begin{array}{c}L \\
(\mathrm{~mm})\end{array}$ & $d_{0} / D_{w}$ & $A_{f} / A_{w}$ & $\frac{b}{2 t_{f}} \sqrt{\frac{F_{y f}}{345}}$ & $\frac{D_{w}}{t_{w}} \sqrt{\frac{F_{y f}}{345}}$ & $\begin{array}{c}\text { 曲げ-せん断 } \\
\text { 作用比 }\end{array}$ \\
\hline 2003 & HY-1 & 129.2 & 11.3 & 673.1 & 5.1 & 673.1 & 1937.4 & 1.0 & 0.9 & 6.9 & 159.8 & 0.60 \\
\hline 2003 & HY-2 & 129.9 & 11.2 & 673.3 & 4.5 & 674.0 & 1388.2 & 1.0 & 1.0 & 7.0 & 178.9 & 0.95 \\
\hline 2003 & HY-3 & 129.2 & 11.2 & 673.1 & 4.6 & 673.1 & 945.5 & 1.0 & 0.9 & 7.0 & 175.0 & 1.37 \\
\hline 2004 & HY-4 & 123.6 & 11.0 & 633.3 & 4.1 & 635.5 & 2108.3 & 1.0 & 1.0 & 7.2 & 196.8 & 0.67 \\
\hline 2004 & HY -5 & 123.5 & 11.2 & 633.3 & 4.2 & 639.4 & 1355.0 & 1.0 & 1.0 & 7.0 & 192.1 & 1.04 \\
\hline 2004 & HY-6 & 123.7 & 11.1 & 635.1 & 4.2 & 634.9 & 950.3 & 1.0 & 1.0 & 7.1 & 192.7 & 1.48 \\
\hline 2004 & HY-7 & 123.2 & 10.7 & 634.7 & 4.1 & 634.7 & 634.7 & 1.0 & 1.0 & 7.3 & 197.2 & 2.36 \\
\hline 2004 & F-1 & 176.5 & 8.1 & 633.6 & 4.1 & 641.1 & 1126.3 & 1.0 & 1.1 & 13.9 & 196.9 & 1.15 \\
\hline 2004 & F-2 & 177.0 & 8.3 & 634.7 & 4.3 & 635.7 & 950.2 & 1.0 & 1.1 & 13.6 & 188.1 & 1.34 \\
\hline 2004 & F-3 & 176.6 & 8.6 & 635.2 & 4.2 & 635.7 & 770.2 & 1.0 & 1.1 & 13.1 & 192.7 & 1.79 \\
\hline 2005 & $\alpha-1.0$ & 133.0 & 11.1 & 673.6 & 4.5 & 673.7 & 1351.1 & 1.0 & 1.0 & 7.08 & 177.0 & 0.64 \\
\hline 2005 & $\alpha-1.5$ & 132.9 & 11.0 & 675.3 & 4.5 & 1012.2 & 1620.7 & 1.5 & 1.0 & 7.10 & 176.6 & 0.99 \\
\hline 2005 & $\alpha-2.0$ & 133.3 & 11.0 & 674.7 & 4.5 & 1353.3 & 1883.0 & 2.0 & 1.0 & 7.12 & 176.9 & 1.59 \\
\hline 2005 & P-1 & 133.5 & 11.0 & 674.5 & 4.5 & 676.7 & 1351.0 & 1.0 & 1.0 & 7.12 & 177.0 & 0.97 \\
\hline 2005 & F-A1 & 103.6 & 9.3 & 674.8 & 4.5 & 676.0 & 1690.8 & 1.0 & 0.6 & 7.02 & 189.8 & 0.97 \\
\hline 2005 & F-A2 & 103.4 & 9.2 & 674.3 & 4.5 & 676.0 & 1085.0 & 1.0 & 0.6 & 7.04 & 188.8 & 0.97 \\
\hline 2005 & F-A3 & 103.2 & 9.3 & 673.7 & 4.5 & 673.7 & 673.7 & 1.0 & 0.6 & 6.96 & 187.8 & 0.97 \\
\hline
\end{tabular}

表-2 引張試験結果

\begin{tabular}{|c||c|c|c|c|c|c|c|c|c|c|c|}
\hline 年度 & 鋼材 & $\begin{array}{c}\text { 板厚 } \\
t \\
(\mathrm{~mm})\end{array}$ & $\begin{array}{c}\text { 断面幅 } \\
b \\
(\mathrm{~mm})\end{array}$ & $\begin{array}{c}\text { 降伏応力 } \\
\sigma_{y} \\
\left(\mathrm{~N} / \mathrm{mm}^{2}\right)\end{array}$ & $\begin{array}{c}\text { 引張強さ } \\
\sigma_{u} \\
\left(\mathrm{~N} / \mathrm{mm}^{2}\right)\end{array}$ & $\sigma_{y} / \sigma_{u}$ & $\begin{array}{c}\text { 降伏ひずみずみ硬化 } \\
\varepsilon_{y} \\
\left(10^{-6}\right)\end{array}$ & $\begin{array}{c}\text { ひずみ } \varepsilon_{s t} \\
\left(10^{-6}\right)\end{array}$ & $\varepsilon_{s t} / \varepsilon_{y}$ & $\begin{array}{c}\text { ポアソン比 } \\
\mu\end{array}$ & $\begin{array}{c}\text { 戦性係数 } \\
E \\
\left(\mathrm{kN} / \mathrm{mm}^{2}\right)\end{array}$ \\
\hline \hline 2003 & SM400 & 4.51 & 25.07 & 297.0 & 394.8 & 0.75 & 1495 & 29957 & 20.0 & 0.28 & 199.6 \\
\hline 2003 & SM570 & 10.84 & 25.14 & 499.7 & 579.2 & 0.86 & 2371 & 24319 & 10.3 & 0.28 & 210.8 \\
\hline 2004 & SS400 & 4.13 & 25.18 & 308.9 & 399.2 & 0.77 & 1420 & 24018 & 16.8 & 0.28 & 215.0 \\
\hline 2004 & SM570 & 8.20 & 40.19 & 562.9 & 646.8 & 0.87 & 2757 & 10012 & 3.6 & 0.27 & 207.5 \\
\hline 2004 & SM570 & 11.07 & 40.39 & 559.7 & 613.3 & 0.91 & 2669 & 31292 & 11.7 & 0.25 & 210.0 \\
\hline 2005 & SS400 & 4.45 & 25.15 & 302.0 & 419.5 & 0.72 & 1402 & 15895 & 11.2 & 0.28 & 215.9 \\
\hline 2005 & SM570 & 9.14 & 25.25 & 543.9 & 645.4 & 0.84 & 2519 & 6728 & 2.7 & 0.25 & 216.2 \\
\hline 2005 & SM570 & 10.77 & 25.18 & 478.4 & 615.3 & 0.78 & 2249 & 10815 & 4.8 & 0.26 & 212.8 \\
\hline
\end{tabular}

ド桁の静的載荷試験を行い，組合せ荷重下におけるせん 断而荷力性状と斜張力場作用に影響を及ぼす要因につい て検討，基礎的データを収集することを目的としている。 また，実験結果と著者らが提案したせん断而荷力式を比 較し，今後の設計式提案に向けての検討を行った.

\section{2. 実験概要}

\section{（1）供試体概要}

本研究で検討した供試体は，表-1に示寸計17体である。 $\alpha$-series $(\alpha-1.0 \sim \alpha-2.0), \quad$ P-1, F-A series(F-A1 F-A3)を2005 年度，HY-series(HY-1〜HY-3)を2003年度，およびHY$\operatorname{series}(\mathrm{HY}-4 \sim \mathrm{HY}-7)$ とF-series(F-1〜F-3)を2004年度に製作， 実験を行った。各供試体の実測寸法を表-1に，概略図を 図-1に示す．年度ごとに鋼材の引張試験を行ったため, ここでは供試体を年度ごとに分類した。

2004年度と2005年度の供試体はフランジにSM570，ウ ェブにSS400を，2003年度の供試体はフランジにSM570， ウェブにSM400を用いたハイブリッド桁である．使用鋼 材の引張試験の結果を表-2に示す。これらは，JIS規格5 号試験片をフランジ(材質SM570，板厚 $9 \mathrm{~mm}, 11 \mathrm{~mm})$ とウ エブ(材質SS400またはSM400，板厚 $4.5 \mathrm{~mm}$ )の鋼材各3本
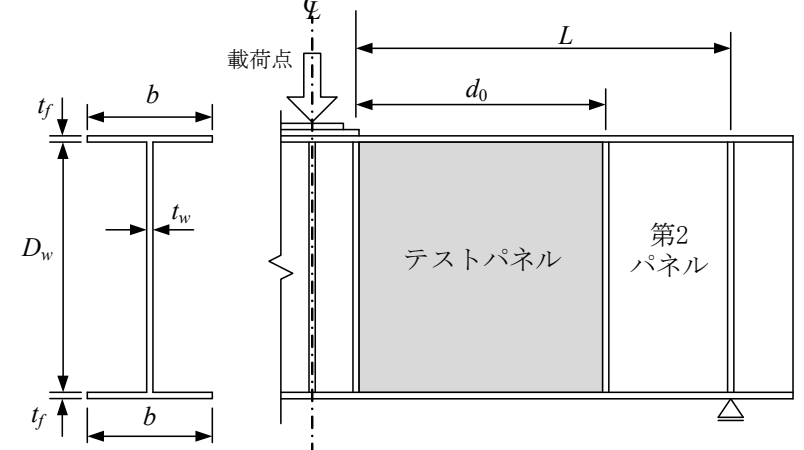

図-1 供試体概略図

製作し，引張試験を行った結果の平均值である。

2003年度および2004年度供試体はテストパネルを載荷 点の両側に設け，2005年度供試体に関しては図-1に示す ように，テストパネルを載荷点の右側のみに設けた。テ ストパネル以外の部分（P-1のテストパネルに隣接する パネルは除く）では垂直補岡材間隔を狭め，予測而荷力 までせん断座屈を起こさないように設計した。補岡材は， $\mathrm{LRFD}^{12)}$ を基に設計し，中間垂直補剛材にSM570(9mm),

支点上補岡材にSM570(11mm)を用いた.

HY-seriesの設計断面寸法は統一し，各供試体の曲げと せん断の作用する割合が同じにならないように桁の長さ を調整した(表-1参照). F-seriesでは曲げとせん断の作用 する割合がHY-5，HY-6とほぼ同じ，あるいはその中間 


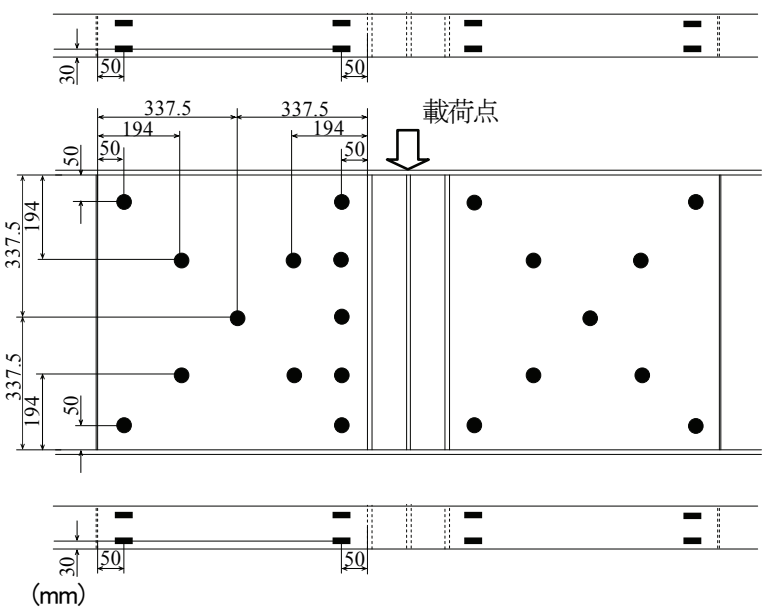

図-2ゲージ配置図 (2003 年度供試体)

となるよう桁の長さを調整した．F-A seriesでは曲げとせ ん断の作用する割合がHY-4，HY-5，HY-6，とほぼ同じ となるように桁の長さを調整した.

さらに，F-seriesではフランジ幅厚比をHY-seriesの約2 倍とし，F-A seriesではフランジ断面積をHY-seriesの約2 分の1としている.

2004 年度版 LRFD では，水平補岡材がなく，アスペク 卜比が 3.0 を超えない間隔で垂直補剛材がある場合，ウ ェブ断面積とフランジ断面積との比率に応じて, ウェブ パネルのせん断而荷力式を次式のように規定している. すなわち，フランジの断面積が小さい場合，斜張力場の アンカー作用が期待できず，耐荷力が低下すると考えて いる．この点を確認するために，前述の通りフランジ幅 厚比, 断面積を変化させた.

$$
\begin{aligned}
& \frac{A_{f}}{A_{w}} \geq 0.8: V_{n}=V_{p}\left[C+\frac{0.87(1-C)}{\sqrt{1+\alpha^{2}}}\right] \\
& \frac{A_{f}}{A_{w}}<0.8: V_{n_{-} F}=V_{p}\left[C+\frac{0.87(1-C)}{\sqrt{1+\alpha^{2}}+\alpha}\right]
\end{aligned}
$$

ここで, $A_{f}$ : フランジ断面積 $\left(=2 b t_{f}\right), A_{w}$ : ウェブ断面積 $\left(=D_{w} t_{w}\right), \quad V_{p}$ : 塑性せん断強度， $\alpha$ : アスペクト比 $\left(d_{0} / D_{w}\right)$, $C:$ せん断座屈応力とせん断降伏応力の比, である.

$\alpha$-seriesは，アスペクト比とせん断而荷力の関係につい て検討するために設計した供試体であり，アスペクト比 がそれぞれ1.0，1.5，2.0となるよう設計した。 断面寸法 については，比較のためHY-series と等しくなるよう設計 した.

P-1は，テストパネルに隣接する第2パネルがせん断而 荷力に及ぼす影響を検討するために設計した供試体であ り，テストパネルと第2パネルの座屈強度がほぼ等しく なるよう設計した. さらに， $\alpha-1.0$ と比較できるよう設計 断面寸法および供試体長さを $\alpha-1.0$ と同じにした.

設計ウェブ幅厚比は $D_{w} / t_{w}=150$ を基準とし，式（1），

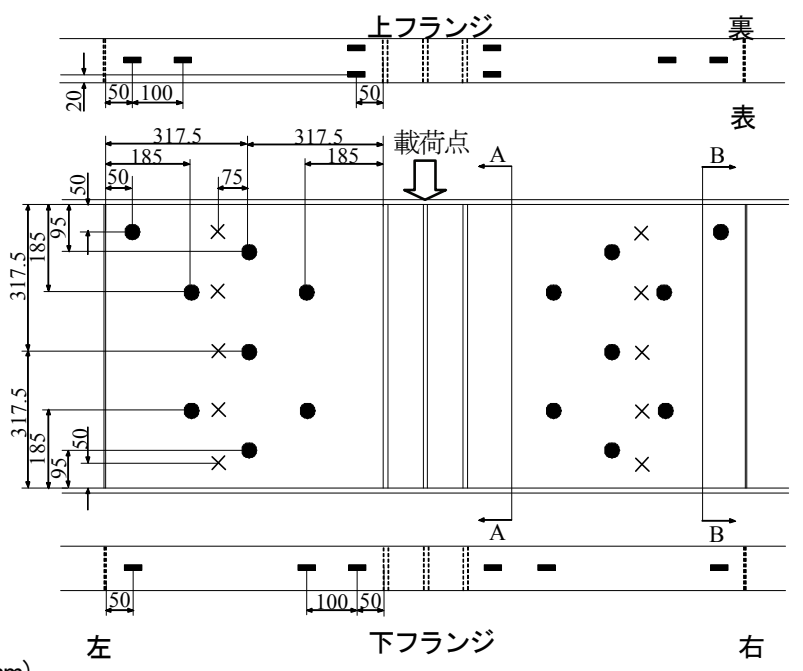

$(\mathrm{mm})$

図-3ゲージ配置図（2004 年度供試体）

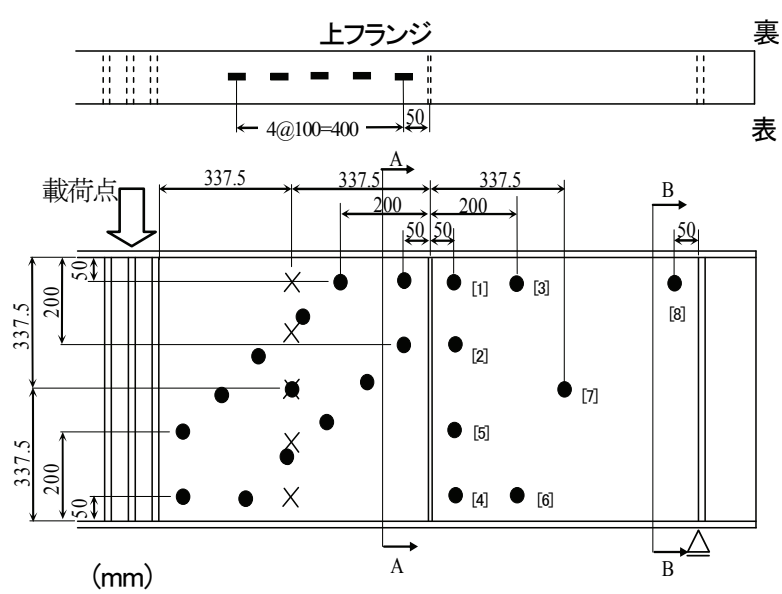

図-4ゲージ配置図（2005 年度供試体）

（2）の適用が可能となるよう，LRFDに規定されている 水平補剛材のないウェブ幅厚比上限值に近い值とした. フランジ幅厚比は，最大耐荷力に達する以前に圧縮フラ ンジが局部座屈を引き起こさないよう，LRFDに規定さ れている厚肉断面の幅厚比制限值内とした. なお， フラ ンジとウェブの換算幅厚比は，使用鋼材の引張試験を行 ってから決定した.

前述の通り，実験供試体の供試体長さは，曲げ一せん 断の作用する割合を変化させるように決定した．曲げー せん断相関図を描く時にはそれぞれを曲げ強度，せん断 強度で無次元化するが，それぞれ式(3)に示す2004年度版 LRFDに規定されている曲げ而荷力式から求まる值，式 (1)のせん断耐荷力式から求まる值，を用いた．せん断耐 荷力式に式(1)を用いたのは，HY-series， $\alpha$-series とF-A seriesを比較しやすくするためであり，考察では式(2)も 用いて整理・比較している.

$$
M_{n}=C_{b}\left[1-\left(1-\frac{\sigma_{y w}}{R_{h} \sigma_{y f}}\right)\left(\frac{L_{b}-L_{p}}{L_{r}-L_{p}}\right)\right] R_{b} R_{h} M_{y}
$$

ここで， $C_{b}$ : モーメント勾配に関する補正係数（1.0と仮 


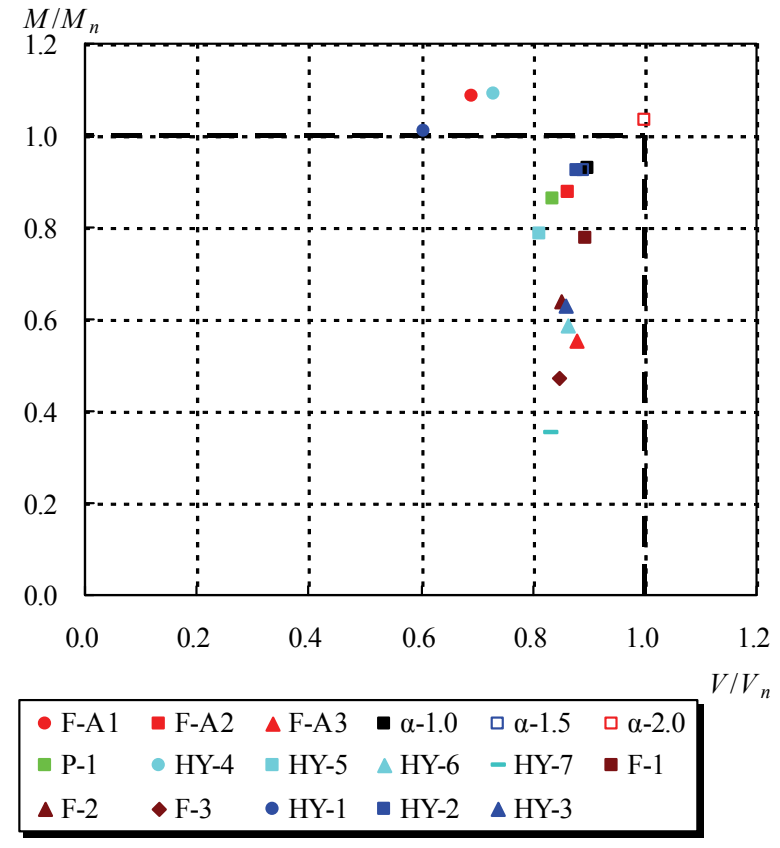

図-5＼cjkstart曲げ一せん断而荷力相関図

定）， $\sigma_{y w}$ : ウェブ鋼材の降伏志力度， $\sigma_{y f}$ : フランジ鋼材 の降伏応力度, $R_{h}$ : ハイブリッドファクター ${ }^{22)}, R_{b}$ : ウ エブの曲げ座屈を考慮する係数, $L_{b}$ : 供試体の横補岡間 隔, $L_{p}$ : 塑性モーメントに達するのに必要な横補剛間隔, $L_{r}$ : 降伏モーメントに達するのに必要な横補剛間隔, で ある。

この無次元化された曲げ一せん断相関図において，各 供試体の載荷経路の傾きを示したもの, すなわち曲げと せん断の作用する割合（本論文では曲げーせん断作用比 と呼ぶ）を表-1に示した。曲げとせん断が同比率と呼ば れる場合は，曲げ一せん断作用比が1.0となり，無次元化 された曲げーせん断相関図において点（1.0，1.0）を通 る載荷経路となる．本論文では，1.2より大きくなるとせ ん断卓越，0.8より小さいと曲げ卓越となるものとした.

\section{（2）実験方法}

供試体の載荷方法は，曲げ一せん断組合せ荷重を想定 する単純ばりの中央一点載荷とした。載荷は，降伏荷重 近くまでは荷重制御で行い，その後はたわみ制御で行っ た。たわみは供試体中央下側に変位計を設置して測定し た.

図-2４にそれぞれ，2003年度，2004年度，および 2005年度の供試体におけるダイヤルゲージおよびひずみ ゲージ位置を示す．前述の通り，2003，2004年度供試体 においては載荷点を挟んで両側のパネルが実験対象テス トパネルであり，2005年度供試体においては片側のパネ ルのみが実験対象テストパネルである.

すべての図において，黒丸が3軸兮ージ，黒四角が1軸 ゲージ，×がダイヤルゲージを示す．ダイヤルゲージは，

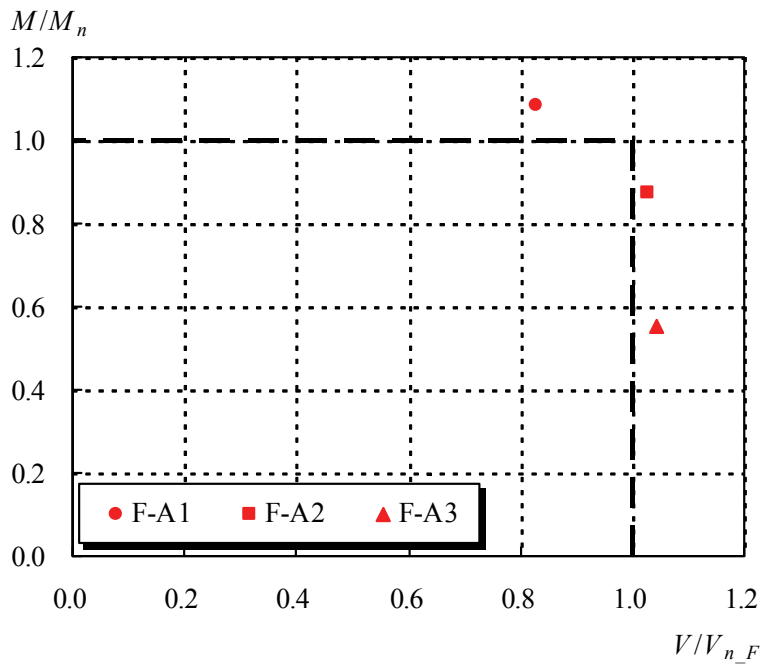

図-6＼cjkstart曲げーせん断而荷力相関図（F-A series）

主に座屈による面外変形を実験中に確認するために用い た.これら図に示されている以外に，垂直補剛材に作用 する応力についても検討するため, 垂直補剛材に1軸兮 ージを貼り付けた.

\section{3. 実験結果および考察}

\section{（1）耐荷力の比較}

表-3に最大荷重時のせん断力および曲げモーメントを 示し，図-5，6に曲げーせん断相関図を示す。図-7には 載荷試験後に撮影した，主な供試体のウェブ崩壊形状を 示す.

表中の添え字はそれぞれ，uが最大荷重時の実験值 （終局強度），nがLRFDで規定されている而荷力を示す。 前述の通り，LRFDが規定しているせん断耐荷力には2種 類あり， $V_{n}, V_{n F}$ はそれぞれ式(1), 式(2)より求めたせん 断耐荷力である. 曲げモーメントの最大值はテストパネ ル内の最大モーメントを, 載荷荷重から求めたものであ る.

ここで，P-1は，テストパネルよりも先に第2パネル (図-1に示すような，テストパネルに隣接するウェブパ ネル）が座屈を起こし（図-7参照）， $\alpha-1.0$ に比べ約7\% の耐力の低下が見られたため, 第2パネルにおける座屈 荷重を表-3に示していることを注記しておく．これは， 供試体製作時の初期変形量が，テストパネルより第2パ ネルの方が大きかったことが原因と考えられる.

図中，縦軸は曲げモーメントをLRFDで規定されてい る曲げ而荷力で無次元化したもの，横軸はせん断力を LRFDで規定されている $V_{n}$ (図-5）および $V_{n-F}$ (図-6）で 無次元化したものである.太破線は曲げ一せん断の相関 がないものとしたLRFDの予測而荷力相関曲線である.

図-5より，明確な曲げ一せん断の相関は確認できない 
表-3 曲げ，せん断而何力一覧

\begin{tabular}{|c|c|c|c|c|c|c|c|c|c|c|}
\hline \multirow{2}{*}{ 年度 } & \multirow{2}{*}{ 供試体 } & $V_{u}$ & $V_{n}$ & $V_{n F}$ & \multirow{2}{*}{$V_{u} / V_{n}$} & \multirow{2}{*}{$V_{u} / V_{n_{-} F}$} & \multirow{2}{*}{$V_{n_{-} F} / V_{n}$} & $M_{u}$ & $M_{n}$ & \multirow{2}{*}{$M_{u} / M_{n}$} \\
\hline & & $\mathrm{kN}$ & $\mathrm{kN}$ & $\mathrm{kN}$ & & & & $\mathrm{kN} \cdot \mathrm{m}$ & $\mathrm{kN} \cdot \mathrm{m}$ & \\
\hline 2003 & $\overline{\text { HY-1 }}$ & $\begin{array}{l}302.3 \\
\end{array}$ & $\bar{~} 498.4$ & - & $\bar{~} 0.61$ & - & - & $\begin{array}{l}585.7 \\
\end{array}$ & $\begin{array}{l}579.7 \\
\end{array}$ & 1.01 \\
\hline 2003 & HY-2 & 370.0 & 420.5 & - & 0.88 & - & - & 513.6 & 556.3 & 0.92 \\
\hline 2003 & HY-3 & 373.9 & 434.2 & - & 0.86 & - & - & 353.5 & 563.5 & 0.63 \\
\hline 2004 & HY-4 & 266.6 & 364.1 & - & 0.73 & - & - & 562.0 & 516.0 & 1.09 \\
\hline 2004 & HY-5 & 305.8 & 376.0 & - & 0.81 & - & - & 414.3 & 527.5 & 0.79 \\
\hline 2004 & HY-6 & 326.8 & 378.3 & - & 0.86 & - & - & 310.6 & 531.8 & 0.58 \\
\hline 2004 & HY-7 & 303.8 & 365.1 & - & 0.83 & - & - & 192.8 & 546.0 & 0.35 \\
\hline 2004 & F-1 & 324.9 & 362.9 & - & 0.90 & - & - & 365.9 & 470.6 & 0.78 \\
\hline 2004 & F-2 & 333.7 & 391.0 & - & 0.85 & - & - & 317.1 & 498.0 & 0.64 \\
\hline 2004 & F-3 & 320.5 & 378.1 & - & 0.85 & - & - & 246.8 & 522.6 & 0.47 \\
\hline 2005 & F-A1 & 292.0 & 421.1 & 352.6 & 0.69 & 0.83 & 0.84 & 493.7 & 455.6 & 1.08 \\
\hline 2005 & F-A2 & 365.5 & 423.6 & 355.5 & 0.86 & 1.03 & 0.84 & 396.6 & 453.5 & 0.87 \\
\hline 2005 & F-A3 & 375.0 & 426.6 & 359.1 & 0.88 & 1.04 & 0.84 & 252.6 & 457.2 & 0.55 \\
\hline 2005 & $\alpha-1.0$ & 381.0 & 423.8 & - & 0.90 & - & - & 514.8 & 553.5 & 0.93 \\
\hline 2005 & $\alpha-1.5$ & 315.0 & 354.1 & - & 0.89 & - & - & 510.5 & 554.0 & 0.92 \\
\hline 2005 & $\alpha-2.0$ & 305.0 & 304.9 & - & 1.00 & - & - & 574.3 & 554.9 & 1.03 \\
\hline 2005 & P-1 & 355.0 & 424.2 & - & 0.84 & - & - & 479.6 & 555.3 & 0.86 \\
\hline
\end{tabular}
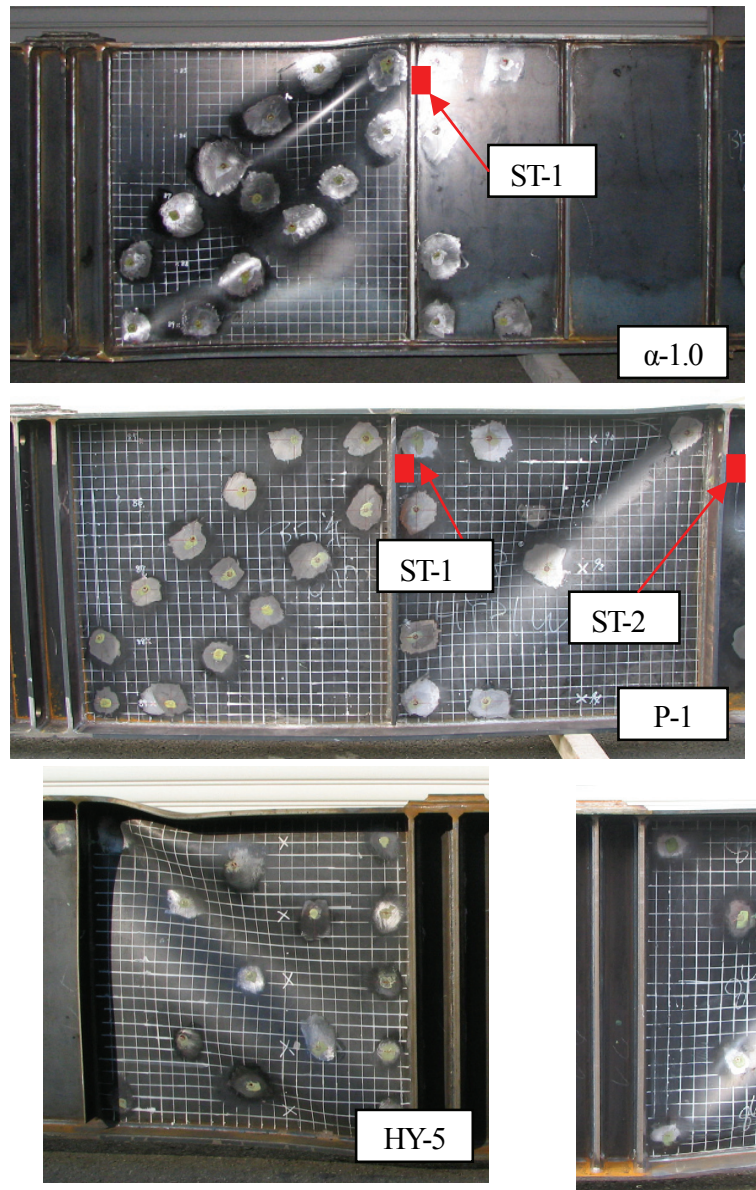

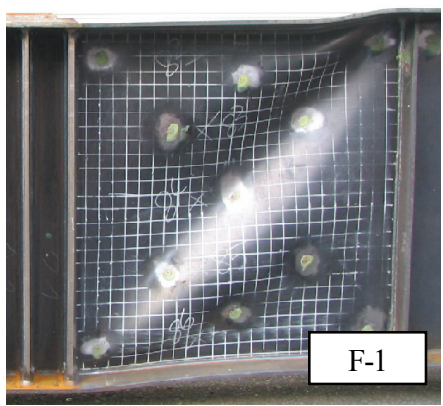

図-7 ウェブ崩壊形状例
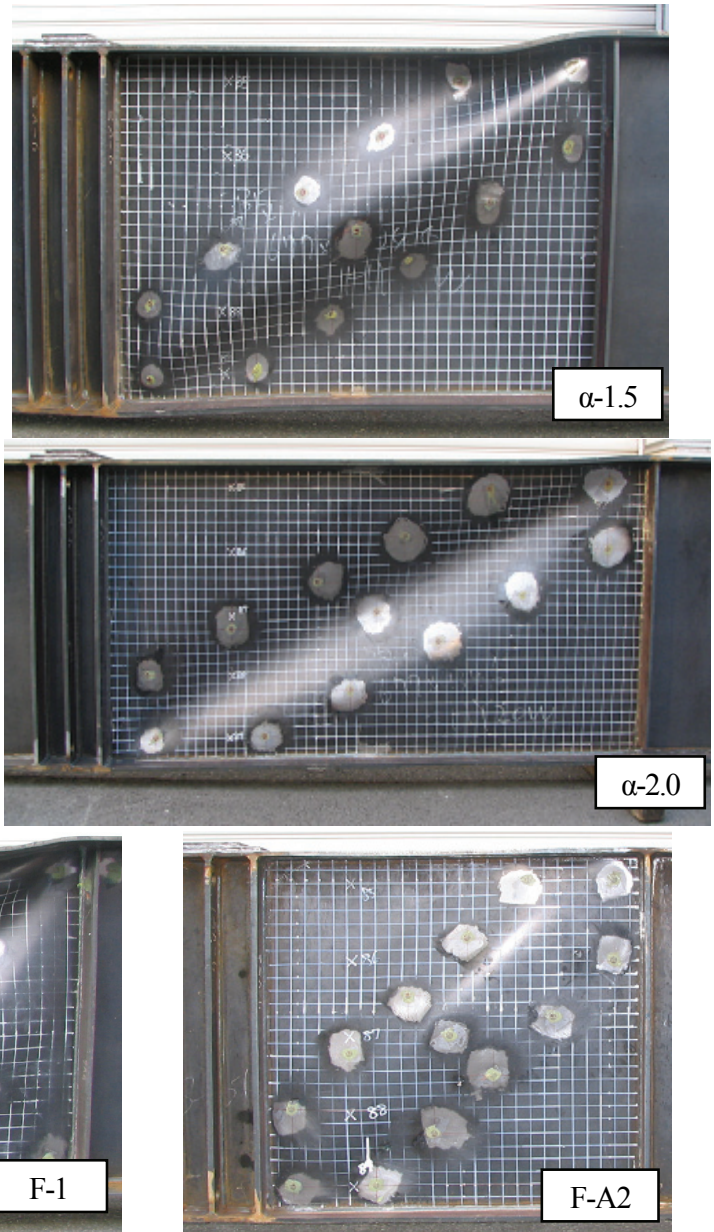

ことが分かる．曲げ卓越の載荷経路をたどる供試体につ いては, 終局荷重時の曲げモーメントはLRFD曲げ耐荷 力（式(3)より求まる值）を上回ることが分かる. 一方, せん断と曲げが同程度のものから，せん断卓越の供試体 においては， $\alpha-2.0$ を除いてLRFDせん断耐荷力（式(1)よ り求まる值）よりも実験值が約10～16\%低い結果となっ

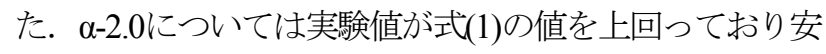
全側の予測值であった，Baslerの式については10\%程度 のばらつきは確認されており ${ }^{30)}$ ，今回の実験結果もおお よそその範囲内であると思われる。 しかしながら，表-3 に示寸 $\alpha-1.0, \alpha-1.5, \alpha-2.0$ の $V_{u} / V_{n}$ の值を比較すると， アスペクト比によってかなり精度が異なる結果となった。 


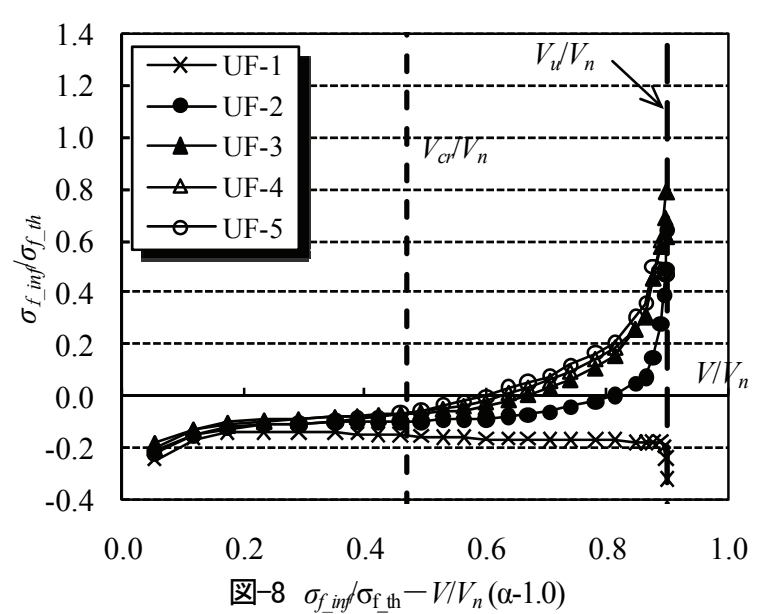

表-4 UF-3 に関する比較

\begin{tabular}{|c||c|c|}
\hline & $\alpha-1.0$ & F-A2 \\
\hline \hline$\sigma_{f_{-} i n f}-\mathrm{Max}$ & 210.4 & 296.4 \\
\hline$\sigma_{y}\left(\mathrm{~N} / \mathrm{mm}^{2}\right)$ & 478 & 543 \\
\hline$V_{f_{y}} / V_{n}$ & 0.898 & 0.859 \\
\hline$V_{u} / V_{n}$ & 0.899 & 0.863 \\
\hline
\end{tabular}

これは，図-7からも分かるように，座屈波形は対角線方 向に見られ，Baslerの式で考慮されているものとは異な ることが原因とも考えられ，設計式として用いるために は，アスペクト比の大きな桁に関して今後も検討が必要 であると思われる，なお，ウェブに貼付けた 3 軸ゲージ により，せん断卓越型の崩壊形状を示した供試体におい ては, ウェブのほぼ全域が降伏した後に終局荷重に達し ていたことが確認された。

F-A seriesのせん断而荷力について, 表-3の $V_{n_{F}} / V_{n}$ より, LRFDではフランジ断面積の減少によって約 $16 \%$ の低減 を見込んでいることが分かる. しかし，F-A2の終局せ ん断強度は同じ載荷経路である $\alpha-1.0$ の約 $4 \%$ の減少にと どまる結果となった．また，フランジの曲け剛性（幅厚 比）を変化させた供試体F-1 とも顕著な差は読み取れず, 本研究で対象とした範囲では, せん断而荷力, および曲 げ一せん断の相関にフランジの剛性・強度が与える影響 は無いと考えられる.

図-6は，LRFDで規定されている通り，F-A1，F-A2， F-A3供試体の結果を式(2)の值を用いて無次元化している. これより， $V_{u} / V_{n_{-}}$は1.0を超えており， $V_{n_{-}}$は安全側の予 測值であることが分かる.

\section{（2）せん断耐荷カとフランジの関係}

前述の通り，フランジ断面積を減少させたF-A2，フラ ンジの曲げ剛性を減少させたF-1においても顕著なせん 断而何力の減少は見られなかった，そこで，フランジ断 面積の変化によるフランジに作用する応力の変化につい て調べるため，図-8，図-9のように $\sigma_{f i n f} / \sigma_{-\_h}$ と $V / V_{n}$ の関係

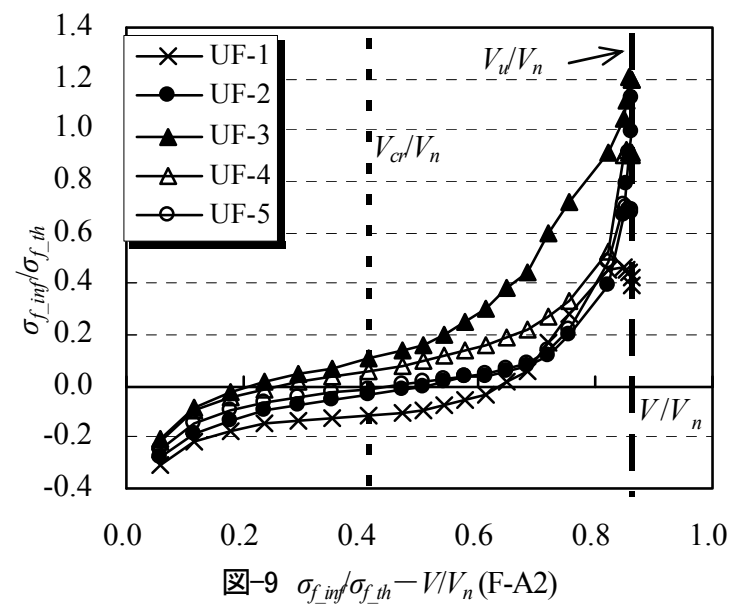

を検討した $\left(\sigma_{f i n f} f \sigma_{-t h}-V / V_{n}\right.$ グラフ）。ここでは，例とし て $\alpha-1.0$ とF-A2のデータを示寸，ただし，本研究で用い た供試体のウェブ幅厚比においては，フランジに塑性ヒ

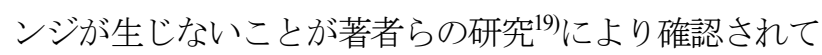
おり，本論文では主にフランジアンカー作用についての 検討を行う。

秥沼とは，ひずみデータに弾性係数を乗じて算出した 応力 $\sigma_{f e x}$ から各ひずみゲージ位置の曲げによる理論応力

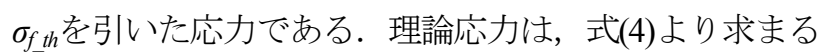
フランジ理論ひずみ $\left(\varepsilon_{f t h}\right)$ に弾性係数を乗ずることによっ て算出される.

$$
\varepsilon_{f_{-} t h}=\frac{M}{E I_{x}} y
$$

ここで, $y:$ 中立軸からフランジ表面までの距離, $M:$ そ の断面におけるモーメント值, $I_{x}$ : 断面2次モーメント, である.

ハイブリッド栴の場合，ウェブ降伏開始までは式(4)を 満足するが，それ以降はウェブ降伏の影響を考慮する必 要がある. しかし，フランジが降伏するまでは，ウェブ 降伏の影響を考慮した理論式から算出した理論ひずみと， 式(4)より算出したひずみとの差異は小さく, 考察に影響 がないと思われるため，ここでは式(4)を用いることとし た. また，フランジが降伏するまでの考察を行うため, フランジが降伏した後は, 実験值は降伏応力度で一定と している.

各ゲージ位置においてそれぞれ理論フランジ応力が異 なるため, 図-8, 図-9の縦軸は $\sigma_{f i n f}$ を $\sigma_{f t h}$ で無次元化した もの, 横軸はせん断力を $V_{n}$ で無次元化したものを示す.

また，図中には座屈せん断力 $\left(V_{c r}\right)$ および終局せん断強 度 $\left(V_{u}\right)$ も示寸.

図中，UF-1〜5まではゲージ位置を示しており，図-4

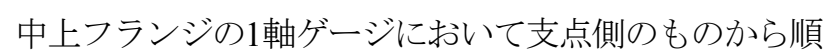
にUF-1〜5となっている.

これらより, せん断座屈時から終局強度に達寸るまで にフランジ応力は理論值よりも大きくなっており, 曲げ 
以外の影響を受けていることが分かる．同じゲージ位置 で比較すると，すべての年ージにおいてF-A2の応力増加 が顕著であることが分かる．また， $\alpha-1.0$, F-A2共に終局 強度付近でUF-3のゲージにおいて最も大きな応力増加が 確認できる.

そこで， $\alpha-1.0$ とF-A2のUF-3におけるデータを整理した ものが表-4である. 表中 $\sigma_{f i n f}-M a x は$ 終局強度時のひずみ データから算出されるフランジ応力とモーメントから梁 理論によって算出される理論值との差, $V_{f y} / V_{n}$ はフラン ジ応力が降伏応力に達した時点でのせん断力を $V_{n}$ で無次 元化したものを示す. $V_{f y} / V_{n}$ と $V_{u} / V_{n}$ の值がほぼ同じであ り, 応力増加が最も大きなUF-3においてフランジ応力が 降伏に達したと同時に終局強度に達していることが分か る.

F-A2の供試体は $\alpha-1.0$ に比べてフランジ断面積を小さく (約2分の1）設計したため, フランジアンカー作用が存 在すれば，フランジ応力の増加分（すなわち $\sigma_{f i n f}$ ) が増 加し，降伏が早まることで斜張力場作用に影響が出るも のと思われていた，ところが，表-4中の終局強度時のフ ランジ応力の理論值との差 $\left(\sigma_{f i n f}-\mathrm{Max}\right)$ の值を比較して 分かるように, 終局荷重時の応力増加は断面積に反比例 しておらず，結果的にほぼ同じ無次元化せん断力の時に 降伏している。これがわずか $4 \%$ の終局強度の違いの理 由であると考えられ，今回の実験供試体では明確なフラ ンジのアンカー作用は認められなかった。

\section{(3) 降伏域の広がりとフランジの応力変化}

本研究で対象とした範囲においては，明確な曲げ一せ ん断の相関は確認できなかった，そこで，曲げーせん断 組合せ荷重のウェブ，およびフランジ内応力への影響に つい検討する.

表-5に，アスペクト比が1の主な供試体の上フランジ に貼り付けた短軸ゲージ（UF-1〜 5）より算出した終局 荷重時の $\sigma_{f i n f}$ の值を, 曲げ卓越の供試体順にまとめてあ る. 2004年度実験供試体についてはテストパネルを載荷
点の左右両方に設けており，検討対象となる上フランジ も2つ存在するが，実験後のウェブ崩壊形状が顕著に見 られたウェブパネル側にある上フランジのひずみゲージ

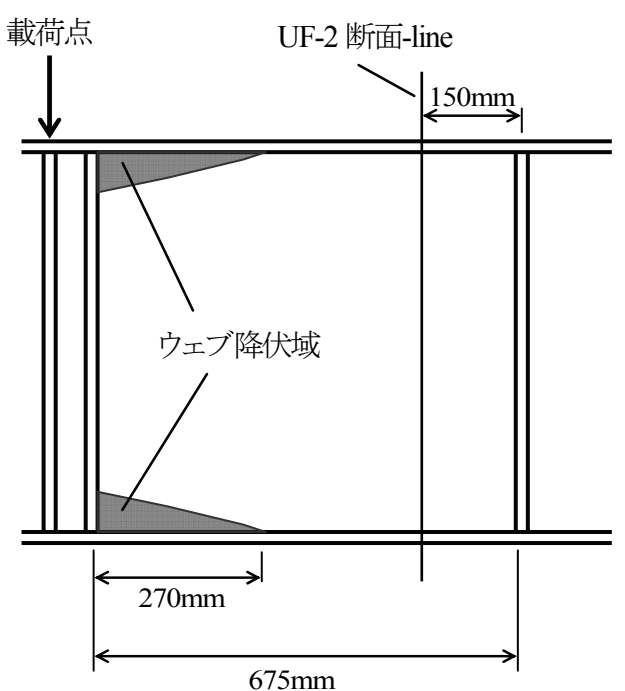

(a) $\alpha-1.0$

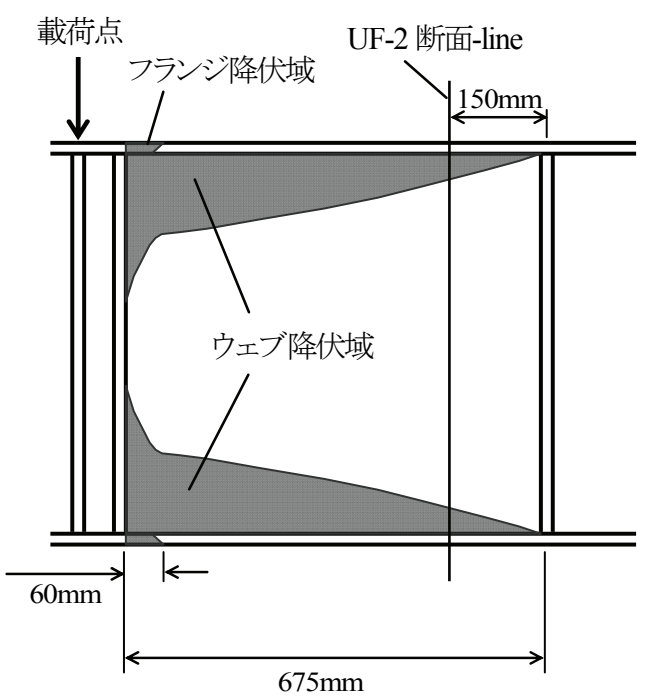

(b) F-A1

図-10 終局荷重時の理論降伏域図

表-5 上フランジの各ゲージ位置における $\sigma_{f \text { fnf }}$ データ

\begin{tabular}{|c|c|c|c|c|c|c|c|c|c|c|c|}
\hline \multirow{3}{*}{\multicolumn{2}{|c|}{$\begin{array}{c}\text { 供試体 } \\
\text { 曲げ-せん断作用 } \\
\text { 比 }\end{array}$}} & F-A1 & HY-4 & $\alpha-1.0$ & F-A2 & HY -5 & F-1 & F-2 & HY-6 & F-A3 & HY-7 \\
\hline & & \multicolumn{2}{|c|}{ 曲げ卓越 } & \multicolumn{4}{|c|}{ 曲げとせん断がほぼ同比率 } & \multicolumn{4}{|c|}{ せん断卓越 } \\
\hline & & 0.64 & 0.67 & 0.97 & 0.99 & 1.04 & 1.15 & 1.34 & 1.48 & 1.59 & 2.36 \\
\hline \multirow{5}{*}{$\begin{array}{c}\sigma_{f_{-} i n f} \\
\left(\mathrm{~N} / \mathrm{mm}^{2}\right)\end{array}$} & UF-1 & 135.5 & 166.9 & -66.9 & 67.2 & 13.3 & -3.4 & -95.0 & -65.0 & -8.8 & 58.7 \\
\hline & UF-2 & 194.8 & 175.9 & 152.4 & 237.1 & 198.9 & 139.2 & 123.9 & 92.8 & 41.8 & 154.6 \\
\hline & UF-3 & 164.9 & - & 210.1 & 295.4 & - & - & - & - & 61.6 & - \\
\hline & UF-4 & 135.0 & - & 181.2 & 257.8 & - & - & - & - & 80.5 & - \\
\hline & UF-5 & 105.1 & - & 152.3 & 220.2 & - & - & - & - & 72.8 & - \\
\hline \multicolumn{2}{|c|}{$P_{f_{\text {inf }}}(\mathrm{kN})$} & - & - & 224.1 & 225.7 & 275.2 & 199.0 & 182.0 & 127.4 & 40.2 & 203.7 \\
\hline \multicolumn{2}{|c|}{$P_{f \text { inf }} / P_{y w}$} & - & - & 0.25 & 0.25 & 0.33 & 0.25 & 0.22 & 0.15 & 0.04 & 0.25 \\
\hline \multicolumn{2}{|c|}{$A_{f} / A_{w}$} & - & - & 0.97 & 0.63 & 1.04 & 1.10 & 1.08 & 1.03 & 0.63 & 1.01 \\
\hline
\end{tabular}


に関して表-5に示している．2003年度実験供試体はフラ ンジに貼り付けたゲージ位置が異なるためここでは載せ ていない.

表には，UF-2における $\sigma_{f \text { inf }}$ と上フランジ断面積の積よ り算出した，フランジ応力増加分に対応する力 $\left(P_{f_{\text {inf }}}\right)$ と, ウェブ断面積に降伏応力を乗じて求められる值（こ こではウェブ降伏強度と呼ぶ）との比 $\left(P_{f_{-i n f}} f P_{y w}\right)$ ，およ びフランジとウェブの断面積比 $\left(A_{f} / A_{w}\right)$ についても示し てある．ただし，曲げ卓越の供試体においては終局強度 に達するまでにUF-2が降伏しており， $P_{f \text { inf }}$ と $P_{f_{\text {_inf }}} P_{y w}$ が他 の供試体と比較できないため載せていない，また，計測 されたひずみ值が，終局荷重までに降伏ひずみを超えた 点については網掛けしてある.

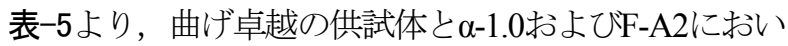
てそれぞれフランジの降伏が確認できる. それぞれの降 伏領域について注目すると，曲げ卓越の供試体ではUF-2 のゲージ位置（垂直補岡材から $150 \mathrm{~mm}$ の位置）まで降伏

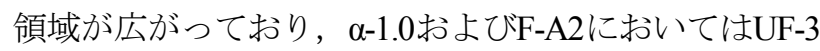
のゲージ位置（垂直補岡材から250mmの位置）まで降伏 領域が広がっていることが分かる.

$P_{\text {finf }}$ に着目すると，HY-7を除いては，曲げとせん断 がほぼ同比率の供試体に比べてせん断卓越の供試体で小 さくなっていることが分かる. また, ウェブ降伏強度で 無次元化した $P_{f_{\text {_inf }}} P_{y w}$ においては，フランジ断面積の違い に関わらず，曲げとせん断が同比率の供試体はほぼ等し く，せん断卓越になるほど減少傾向にあることが分かる. もし，フランジの理論曲げ応力以上の応力増加がアンカ 一作用によるものであれば, $P_{f_{-} \text {inf }} P_{y w}$ の值は曲げ一せん断 の比率に関わらず同程度となることが予想される。 した がって, 本実験結果に見られるフランジの応力増加は, フランジのアンカー作用ではなく，おもにウェブで受け 持たれていた曲げ応力がウェブ座屈の進展によりフラン ジに再分配されたことによるものであると考えられる.

終局荷重時におけるウェブ内の理論曲げ応力分布につ いて検討するため図-10を作成した。これは， $\alpha-1.0$ と FA1のテストパネルを側面から見た，終局荷重時の理論降 伏域を示したものである. 図中のUF-2断面-lineは, UF-2 のゲージ位置を示す.

図-10(b)より，曲げ卓越の供試体であるF-A1は，テス トパネルのほぼ全域でウェブの部分的な降伏が確認でき， UF-2断面ではウェブ上下端が降伏していることが分かる. また，載荷点付近においてはフランジも降伏する．この ような降伏域の広がりに関しては，曲げ卓越であるHY-4 供試体についても同様な結果が得られた。一方，その他 の供試体については，図-10(a)に示すように，載荷点付 近のウェブが部分的に降伏するのみとなった.

このように，曲げとせん断が同比率の供試体やせん断 卓越の供試体については，ハイブリッド桁であってもウ

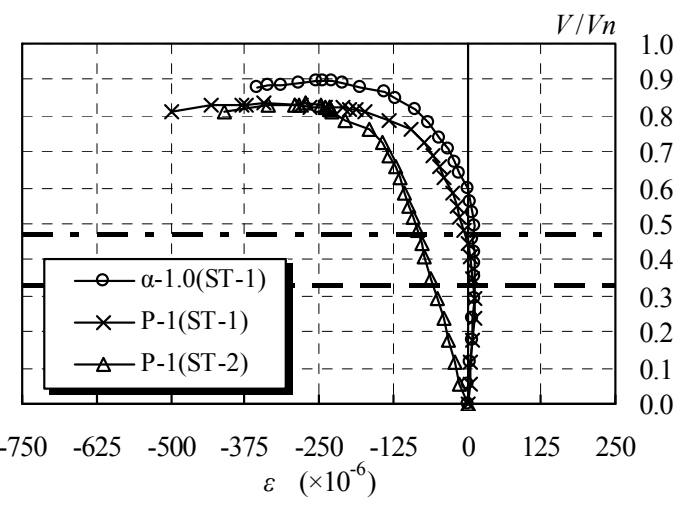

図-11 補岡忉の $V / V_{n}-\varepsilon$ 関係

エブの先行降伏領域は局所的，あるいはほとんど認めら れない程度であり，せん断耐荷力に与える影響は小さい, すなわち曲げーせん断の相関が無い原因になったと考え られる。

\section{（4）補剛材のアンカ一作用}

補岡材の斜張力場作用に対するアンカー作用が存在す れば，ウェブのせん断座屈後のひずみ変化量がせん断座 屈前と比べて異なると考えられる. そこで， $\alpha-1.0$ とP-1 の供試体の補剛材に貼り付けたひずみゲージを用いて $V / V_{n}-\varepsilon$ グラフを描き, ウェブせん断座屈後のひずみ変化

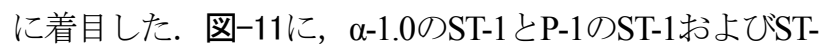
2に関する $V / V_{n}-\varepsilon$ グラフを示す.

ST-1 とはテストパネルを囲む支点側に位置する垂直補 剛材の上フランジ側, ST-2とはテストパネルの隣のパネ ル（第2パネル）の支点側の垂直補岡材（すなわち支点 上補剛材）の上フランジ側に位置している（図-7中赤い 四角で示す）。図中, 縦軸が無次元化せん断力, 横軸が ひずみであり， $\alpha-1.0$ (一点鎖線）とP-1（破線）のせん 断座屈時のせん断力も合わせて示してある.

ST-1について， $\alpha-1.0$ とP-1は共にせん断座屈時から終局 強度に達するまでほぼ等しい挙動を示しているが, ウェ ブせん断座屈後，ひずみ変化量が増加していることが分 かる.しかしながら，式(5)に示す，Baslerの理論式から 予測される終局荷重時の垂直補剛材に作用する圧縮ひず

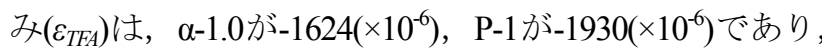
この理論圧縮ひずみに比べて今回の実験結果は共に約 17\%であった. よって，このひずみ変化量の増加が斜張 力場作用に対するアンカー作用によるものではないと考 えられる.

$$
\varepsilon_{T F A}=\frac{V_{u}-V_{c r_{-} \exp }}{E A_{\text {stiff }}}
$$

ここで, $V_{u}$ : 終局荷重時のせん断力（実験值）， $V_{\text {crexp }}$ ： せん断座屈時のせん断力（実験值）， $A_{\text {stiff }}$ : 垂直補剛材 の断面積, である. なお， $V_{\text {crexp }}$ はウェブに貼付けた 3 軸 


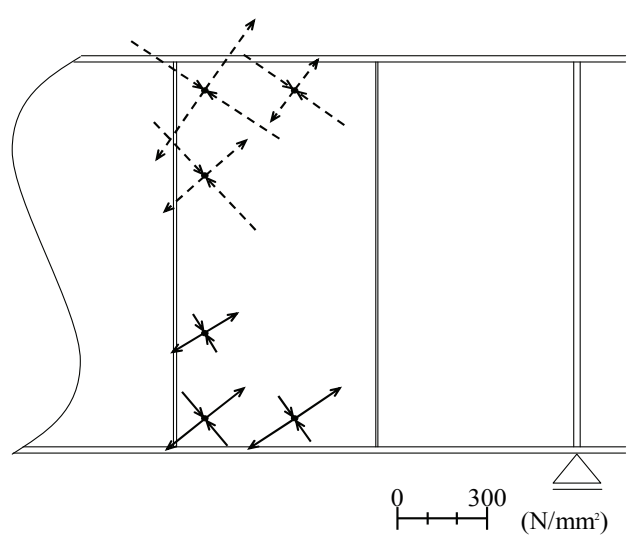

図-12 終局荷重時の主応力分布 $(\alpha-1.0)$

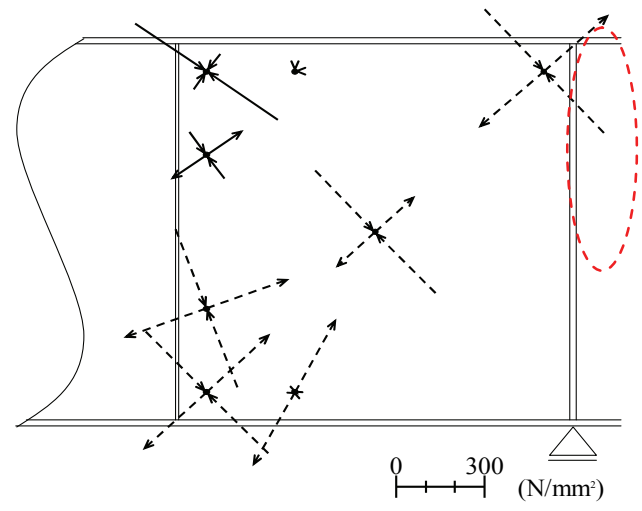

図-13 終局荷重時の主応力分布(P-1)

ゲージにより計測されたひずみ值，およびウェブの面外 変形の計測值より荷重一ひずみの2乗（および面外変形 量の2乗) のグラフを描くことにより決定した.

\section{（5）第 2 パネルのせん断耐荷力}

第2パネルにおける斜張力場作用の発生を考察するた めに, せん断座屈時から終局荷重時までにおける第2パ ネルの応力状態の変化に着目寸る. 図-12, 図-13に第2

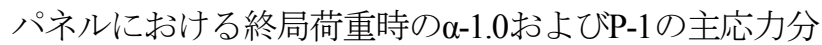
布を示寸（これらは，図-4における[1]〜[8]のゲージであ

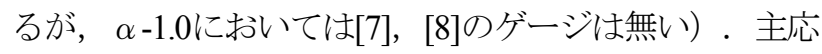
力は計測点に向う矢印が圧縮応力, 外に向う矢印が引張 応力を示し, 点線はvon Misesの降伏条件により降伏した と判断された後のデータであることを示している.

$\alpha-1.0$ とP-1を比較すると， $\alpha-1.0$ の第2パネル上側に貼り 付けた[1]〜[3]すべてのゲージが 降伏灾力に達した後に 終局荷重に達しているのに対して, 第2パネル下側では P-1 に貼り付けた[4]〜6]全てのゲージが降伏応力に達し た後に終局荷重に達していることが分かる．これは，第 2パネルにおける座屈，すなわち斜張力場作用の有無に よるものであると考えられる.

$\alpha-1.0$ はテストパネルに発生した斜張力場作用の一部と して, 隣接する第2パネル上部の応力が増加し, 降伏し たことで而荷力の低下が生じたと考えられる，一方，P-

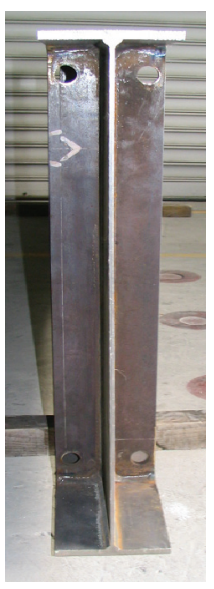

(a) $\alpha-1.0$

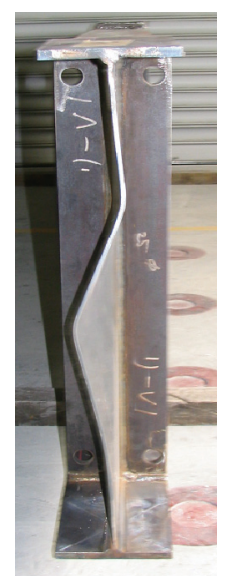

(b) P-1
図-14 実験終了後の端パネル面外変形

1は，テストパネルで発生した斜張力場作用により降伏 する前に，第2パネルで発生した斜張力場作用の一部と しての端パネル上側（図-13中赤点線付近）が，斜張力 場作用による力に抵抗できなくなったことで而荷力の低 下が生じたと考えられる。これは，図-14に示寸実験終 了後の端パネル変形写真において, $\alpha-1.0$ と比較してP-1 では端部のウェブ変形が顕著であることからも確認でき る.

図-13に示寸終局荷重時における支点上補剛材の圧縮 ひずみ(前述のST-2にて計測)は，降伏ひずみ(表-2参照)の 約 $12 \%$ であり, 支点上補剛材は十分な強度を有していた と考えられる.

これらのことから，今回，斜張力場作用に影響を及ぼ した要因としては, 補剛材の剛性や強度ではなく, 隣接 するウェブパネルの座屈変形に対する拘束条件であった と考えられる.

LRFDで規定されている端パネルのせん断耐荷力式は, 式(1)，(2)に示すウェブパネルのせん断耐荷力式とは異な り，せん断座屈強度 $\left(V_{c r}\right)$ までとしている。 しかし，本実 験結果では，P-1の耐荷力は $\alpha-1.0$ に比べ約7\%の低下に留 まり, せん断座屈後も荷重増加が見られるため, LRFD で規定されているほどせん断而何力を低減する必要はな いものと考えられる.

\section{4. 実験結果とせん断耐荷力予測式との比較}

本研究で得られた実験結果と, 著者らが提案したハイ ブリッド析のせん断而荷力予測式 ${ }^{19)}$ ，式(6)，を比較する.

$$
V_{u}=\frac{2 C}{1+\alpha^{2}} t_{w}(1-\gamma) \sigma_{y w} \alpha^{0.7 \gamma}+\tau_{c r} D_{w} t_{w}
$$

ここで, $\quad \gamma=\frac{\tau_{c r}}{\tau_{y w}}, \quad \alpha=\frac{d_{0}}{D_{w}}, \quad C=\frac{1}{4} d_{0}, \tau_{c r}:$ Basler のせ 


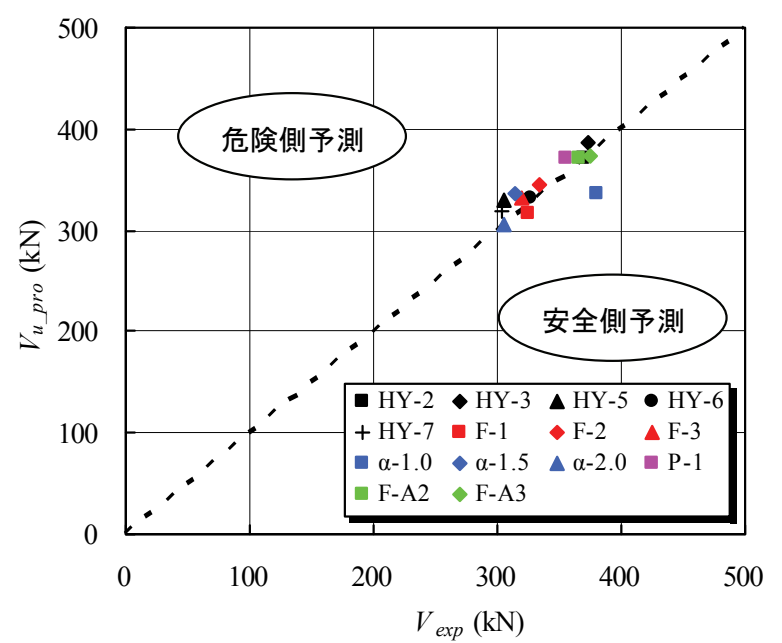

図-15 実験結果と提案式(式(6))との比較

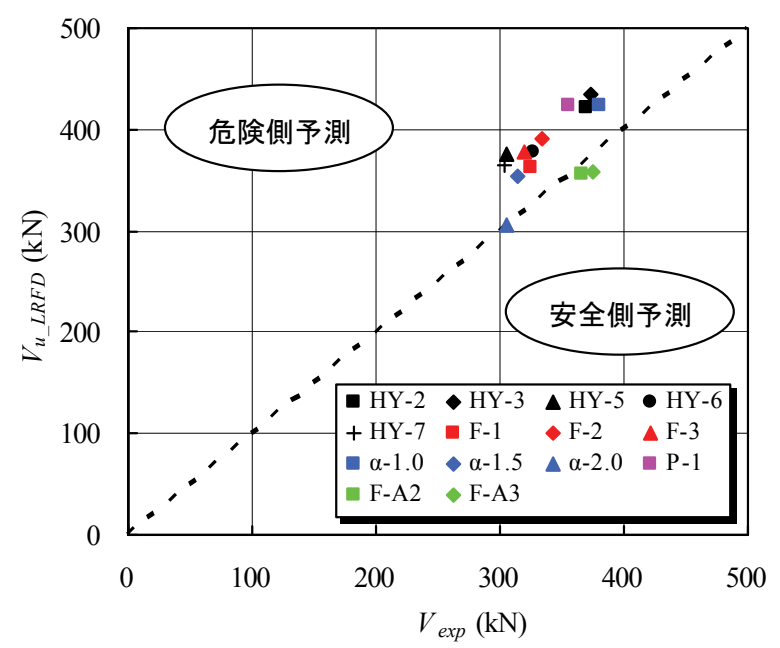

図-16 実験結果とLRFD(式(1), 式(2))との比較

儿断座屈応力, である.

この提案式は，崩壊形状として以下のような点を考慮 に入れて提案されている.

・斜張力場作用は対角線方向に生じる

・ウェブのせん断座屈変形により而荷力の低下が生じる

・フランジ，垂直補剛材のアンカー作用は無い

これらは，本論文で示された考察と一致しており，提 案式の妥当性が確認できた。. また, せん断而荷力式の導 出において考慮した仮定は次の通りである.

1) 垂直補剛材で補剛された内部のウェブパネルに関す るせん断而荷力理論であり，水平補剛材及び桁端部 のウェブパネルに関しては考慮に入れていない。 ま た，非対称断面に関しても考慮に入れていない。

2）垂直補剛材については，Lee $~^{28)}$ が考える後座屈強 度を $100 \%$ 発揮できる岡性を有する.

3）ウェブパネルの支持条件は4辺単純支持.

4) 提案式のウェブパネルに作用する曲げ一せん断の割 合に関する適用範井は，純せん断のものから $M / M_{n}$ 之
$V / V_{n}$ が $1: 1$ の範囲内とする. これより曲げが卓越す るものに関しては，曲げ耐荷力式に従うものとする. 式（6）と本研究の実験結果のうち曲げ卓越の供試体 を除いたものとを比較した結果を図一15に示す，縦軸が 式（6）の值, 横軸が実験值であり, 斜め点線より左側 の点が危険側の予測，右側が安全側の予測であることを 示す．また，同様なグラフを，LRFDで採用されている 式（1），式（2）により求められる值を用いて作成した ものを図-16に示す.

これらより，提案式は LRFD で採用されている式より もばらつきが少なく, より実験值に近い值が算出されて いることが分かる，予測值（提案式または LRFD 式）／ 実験值の平均值で比較すると, 提案式では 1.02, LRFD 式では 1.12 である.

今後はより多くのデータ，特にアスペクト比が大きな ものとの比較を行い，提案式の適用範囲について検討寸 る必要がある。

\section{5. あとがき}

本研究では, 曲げ一せん断組合せ荷重を受けるハイブ リッド栴の静的載荷試験を行い，せん断而何力に影響を 及ぼす要因について検討した. 本研究で検討した項目に 関する主な結論を以下に示す。

1) 本実験供試体において，LRFD で規定されているせ ん断而荷力式は, $A_{f} / A_{w} \geqq 0.8$ (式(1)）に対してばら つきの範囲内ではあるが危険側の予測となった。 スペクト比によってはさらにばらつきが大きくなり アスペクト比が大きい供試体についてはさらなる検 討が必要と思われる. 一方, $A_{f} / A_{w}<0.8$ (式(2)）に おいては，安全側の予測式であることが分かった.

2) 本研究で検討した幅厚比では, フランジ断面積の減 少によるせん断耐荷力の変化（約 4\%減）は，

AASHTO で規定されている (約 16\%減) ほど明確 には現れず，フランシ風性を変化させた場合にもせ 儿断而荷力への影響は少ない.

3）本実験で対象とした範囲においては, 曲げ一せん断 の相関は存在しないことが分かった。これは，八イ ブリッド林であってもウェブの先行降伏領域は局所 的，あるいはほとんで認められない程度であり，せ ん断而荷力に与える影響が小さいためであると考え られる。

4) 垂直補剛材の明確なアンカー作用は確認することが できなかった。

5) 斜張力場が形成されるパネルに隣接する第 2 パネル にまで斜張力場が広がっており，この第 2 パネルの 一部も含めてウェブが降伏することにより終局強度 


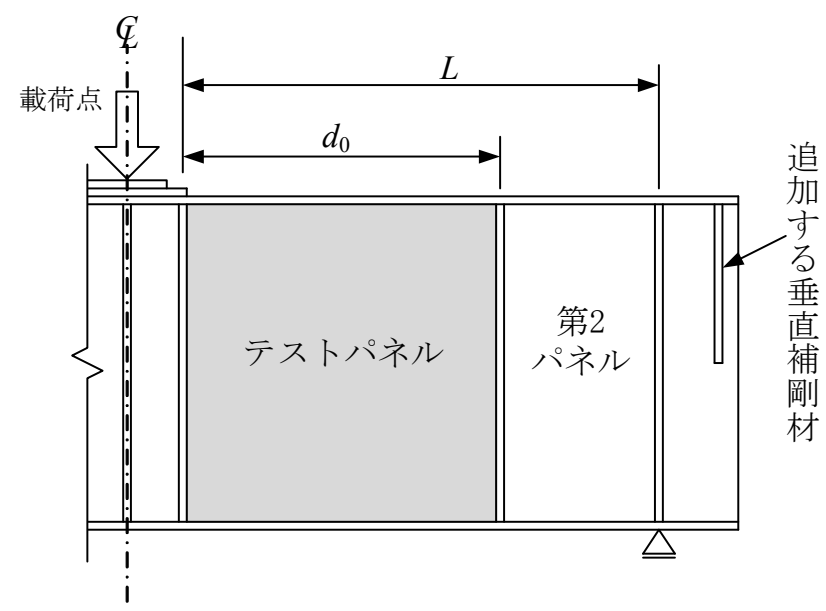

図-17 端パネル補剛方法一例

に達することが分かった。

6) 端パネルにおいても斜張力場が発生し，LRFD に規 定されているようなせん断而荷力の低減は安全側過 ぎるケースもあることが分かった.

7) 著者らが提案したせん断耐荷力式（式（6））は, LRFD の式（1），式（2）と比較しても実験值によ り近い值を算出できることが分かった.

今後は，本研究供試体よりウェブ幅厚比を厚肉断面と した場合，大きなアスペクト比を有する場合，端パネル に垂直補剛材を設けること（たとえば図-17に示すよう に）によって補強した場合のせん断耐荷力の変化につい て検討する必要があると考えられる，また，実験結果を 提案式と比較し適用範囲を確認する.

\section{参考文献}

1)超鉄鋼を活用した高性能士木・建築構造に関する検討小 委員会 : 超鉄鋼の構造物への利用技術についての検討,

JSSC, No. 53, pp.1-10, 2004.

2) 三木千壽, 市川篤司, 楠隆, 川端文丸 : 橋梁用高性能鋼 材（BHS500, BHS700）の提案, 土木学会論文集, No. 738/I-64, pp.1-10, 2003.

3) (社)日本鋼構造協会 : 限界状態設計法に基づいたハイブ リッド栴の設計基準(案), 2002 .

4) (社)日本鋼構造協会 : 合成桁の限界状態設計法試案, 2006.

5) Climgenpeel, B. F. and Barth, K. E.: Design Optimization Study of a Three-Span Continuous Bridge Using HPS70W, Engineering Journal, AISC, Vol.40, No.3, pp.149-158, 2003.

6) Barker, M. G and Schrage, S. D.: High-Performance Steel Bridge Design and Cost Comparisons, Transportation Research Record, Journal of the Transportation Research Board 1740, pp.33-39, 2000.

7) Haaijer, G: Economy of High Strength Steel Structural Members, Journal of Structural Division, ASCE, Vol.87, No.ST8, New York, NY, pp.1-23, 1961.
8) Joint ASCE-AASHTO Subcommittee on Hybrid Beam and Girders: Design of Hybrid Steel Beams, Journal of Structural Division, ASCE, Vol.94, No.ST6, New York, pp.1397-1426, 1968.

9) Schilling, C. G: Bending Behavior of Composite Hybrid Beams, Journal of Structural Division, ASCE, Vol.94, No.ST6, New York, pp.1945-1964, 1968.

10) Schilling, C. G: Behavior of Hybrid Beams Subjected to Static Loading, Journal of Structural Division, ASCE, Vol.90, No.ST3, New York, pp.55-88, 1964.

11) AASHTO: LRFD Bridge Design Specifications, 2nd. Edition, AASHTO, Washington, D.C., 1998.

12) AASHTO: LRFD Bridge Design Specifications, 3rd. Edition, Washington, D.C., 2004.

13）國広哲男, 古庄通隆: ハイブリッドゲターその力学的挙 動と経済性一，橋梁と基礎，pp.1-8，1974.

14）井上啓一：ハイブリッド桁，土木技術資料， 17-7, pp.25-28, 1975.

15）金子洋文，木村衛，大島基義 : ハイブリッド梁の塑性変 形能力について, 日本建築学会学術講演梗概集, pp.1325-1326, 1989.

16) Ito, M., Nozaka, K., Shirosaki, T., and Yamasaki, K. : Experimental Study on Moment-Plastic Rotation Capacity of Hybrid Beams, Journal of Bridge Engineering, ASCE, Vol. 10, No. 4, pp.490-496, 2005.

17) 増田友哉, 野阪克義, 伊藤満, 鈴木正典 : HT690 材の非 弾性設計一の適用に関する実験的研究，鋼構造年次論文 報告集，第 11 巻, pp.393-400， 2003.

18）竹谷純一, 野阪克義, 奥村学, 伊藤満 : ハイブリッド桁 の後座屈強度に関する実験的研究，鋼構造年次論文報告 集, 第 14 巻, pp.507-514, 2006.

19）前田亮太，野村昌孝，野阪克義，奥村学，伊藤満 : 八イ ブリッド桁の斜張力場作用を考慮したせん断而荷力に関 する研究，構造工学論文集，Vol.53A，pp.97-108， 2007.

20）清水茂, 張健, 中田知志, 田中伸尚, 中井博 : ハイブリ ッド鋼林における補剛材の効果，鋼構造論文集，Vol.10, No.37, pp.43-50, 2003.

21）清水茂, 張健, 田中伸尚, 明橋克良, 中井博 : ハイブリ ッド鋼桁の而荷力挙動に関する実験的研究, 鋼構造論文 集, Vol.10, No.37, pp.51-60, 2003.

22）利根川太郎，山口隆司，杉浦邦征，渡邊英一：薄肉少補 剛ウェブ合成ハイブリッド箱桁の正曲げ終局強度に関す る解析的研究, 土木学会論文集 A, Vol.62, No.2, pp.300-311, 2006.

23) 日本道路協会 : 道路橋示方書 - 同解説 I 共通編，II 鋼橋 編, 2002

24) Basler, K.: Strength of Plate Girders in Shear, Journal of Structural Division, ASCE, Vol.87, No.ST7, pp.151-180, 1961. 
25) Basler, K.: Strength of Plate Girders under Combined Moment and Shear, Journal of Structural Division, ASCE, Vol.87, No.ST7, pp.181-197, 1963.

26) Porter, D. M., Rockey, K. C. and Evans, H. R.: The Collapse Behavior of Plate Girders Loaded in Shear, The Structural Engineer, Vol.53, No. 8, pp.313-325, 1975.

27) Lee, S. C. and Yoo, C. H.: Experimental Study on Ultimate Shear Strength of Web Panels, Journal of Structural Engineering, ASCE, Vol.125, No.8, pp.838-846, 1999.

28) Lee, S. C., Yoo, C. H. and Yoon, D. Y.: Behavior of Intermediate Transverse Stiffeners Attached on Web Panels, Journal of Structural Engineering, ASCE, Vol.128, No.3, pp.337-345, 2002.

29) Galambos, T. V. (ed.): Guide to Stability Design Criteria for Metal Structures, 4th. Ed., Structural Stability Council, John Wiley \& Sons, New York, 1988.

30)玉田和也，小野潔，川村暁人，西村宣男 : 鋼逆 $\pi$ 形箱桁
橋架設系のせん断而荷性能に関する実験的研究，土木学 会論文集，No.808/I-74，pp.33-45， 2006.

31）藤野真之 : 初期不整を有するプレートガーダーの組合せ 強度に関する実験的研究，土木学会論文報告集，Vol.269， pp.1-16, 1978.

32）小松定夫, 森脇良一, 藤野真之, 滝本哲四郎 : 組合せ荷 重を受けるプレートガーダーの極限強度，土木学会論 文報告集，Vol.321，pp.1-14，1982.

33）大垣賀津雄, 川口喜史, 磯江暁, 高橋昭一, 川尻克利, 長井正嗣 : 合成 2 主桁橋の鋼主桁補岡設計に関する実験 的研究, Vol.44A, pp.1229-1239, 1998.

34) Hurst, A. M.: Tension Field Action in HPS Hybrid Plate Girders, Master's Thesis, University of Missouri-Columbia, 2000.

(2007. 7.9 受付)

\section{A STUDY ON SHEAR STRENGTH OF HYBRID PLATE GIRDERS UNDER COMBINED LOADING}

\section{Junichi TAKETANI, Katsuyoshi NOZAKA, Manabu OKUMURA and Mitsuru ITO}

Because of the development of high performance steel and the increasing attention on the performance based design in recent years, the application of hybrid plate girders have been investigated. However, it seems that there have not been sufficient experimental and analytical data to propose specifications for performance based design. In this paper, 17 hybrid girders were fabricated and statically tested with various combinations of moment and shear. The results indicated that there was no significant interaction between moment and shear strength based on stress distributions in web panels. In addition, the test results confirmed that the proposed equation by authors gives more reasonable estimation for the shear strength of hybrid girders. 